\title{
VÝVOJ SYSTÉMŮ ŘÍZENÍ VŠECH ČTYŘ KOL
}

\section{DEVELOPMENT OF ALL FOUR-WHEEL STEERING SYSTEMS}

\author{
Jan Němec ${ }^{1 *}$, Petr Jilek ${ }^{1}$
}

\begin{abstract}
Abstrakt Př́spěvek se zabývá rešerší v současné době velmi prosazovaným systémem ř́zení všech čtyr̆ kol u silničních vozidel, a to zejména u osobních vozidel. Shrnuje historický vývoj jednotlivých systémů a popisuje jejich výhody a nevýhody z technického pohledu na konstrukční celek. Zaměruje se i na systémy používané v současných automobilech, které jsou stále velice ojediněle zabudované do nově vyráběných vozidel.
\end{abstract}

Klíčová slova: ř́zení všemi koly, 4WS, mechanické řízení, převodka ř́zení, elektrohydraulické ř́zení, elektromechanické ř́zení, ř́dicí jednotka, elektromotor

Summary The paper deals with a search of the currently very popular system of all four wheels for road vehicles, especially for passenger cars. It summarizes the historical shift of individual systems and describes their advantages and disadvantages a technical point of view of the structural unit. It also focuses on systems used in today's cars, which are still very rarely built into newly manufactured vehicles.

Keywords: $\quad$ all wheel steering, four wheel steering, mechanical steering, steering gear, electrohydraulic steering, electromechanical steering, electronic control unit, electromotor

\section{1. ÚVOD}

K ř́ízení automobilu dochází natočením kol řídící nápravy kolem rejdové osy. Aktuální poloha natočení kol je dána požadavkem řidiče natočením volantu. Natočení rejdových kol zadní nápravy vůči rejdovým kolům přední nápravy je v souhlasném nebo v nesouhlasném smyslu anebo kola zůstávají ve výchozí poloze. Tento systém přináší značné výhody v manévrovatelnosti a ovladatelnosti a je stále více využíván ve vozidlech osobní dopravy.

\footnotetext{
1 Univerzita Pardubice, Dopravní fakulta Jana Pernera, Katedra dopravních prostředků a diagnostiky, Studentská 95, 532 10, Pardubice, ČR

* korespondenční autor, tel.: +420 721083 383, e-mail: nemec.jan@upce.cz
} 


\section{PODSTATA SYSTÉMU 4WS}

\subsection{Vzájemné natočení kol}

U automobilu, který má řídící kola přední nápravy a zadní kola zůstávají ve výchozí poloze, vzniká při natočení kol do rejdu na prodloužené ose zadní nápravy pól otáčení $P$. (viz obr. 1 )

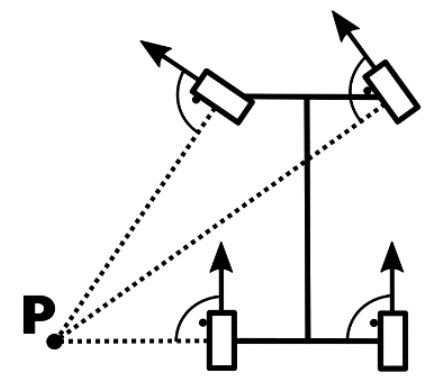

Obr. 1 Kola zadní nápravy ve výchozí poloze

U NESOUHLASNÉHO (opačného) vzájemného natáčení předních a zadních kol se pól otáčení $P$ automobilu posouvá blíže k přední nápravě. Tímto je automobil schopen zatočit na menším poloměru. Využívá se při nízkých rychlostech, třeba při parkování. (viz obr. 2).

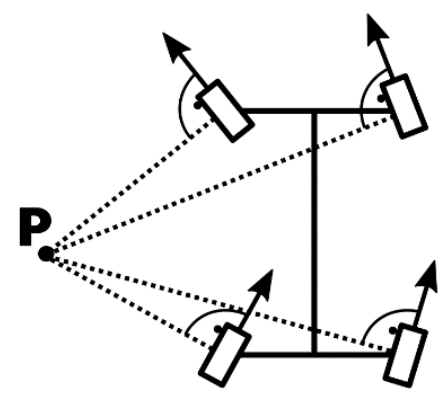

Obr. 2 Nesouhlasné natáčení kol obou náprav

U SOUHLASNÉHO (shodného) vzájemného natáčení předních a zadních kol se pól otáčení $P$ automobilu posouvá za osu zadní nápravy. Tímto se u automobilu snižuje stáčivý moment vozidla a vozidlo se chová stabilněji. Využívá se při vyšších rychlostech, třeba při předjíždění (Pokorny, Jilek, 2014). (viz obr. 3)

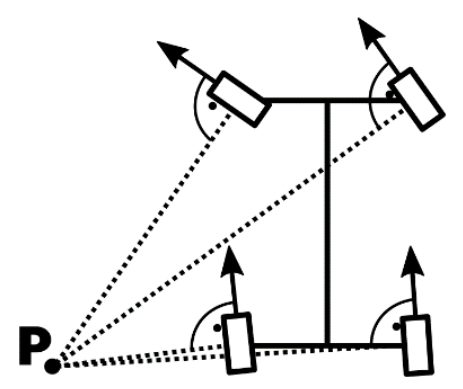




\subsection{Strategie řízení všech čtyř kol}

Cílem řízení všech čtyř kol vozidla je dosáhnout lepší stability vozidla a jeho ovládání. K úspěšnému řízení je třeba vytvořit teoretický model chování vozidla. Strategii úspěšného dosažení cílů lze rozdělit do dvou částí. První je sledování rychlosti vybočení vozidla a snížení úhlu bočního skluzu na nulu. Druhou částí je eliminovat účinky modelových nejistot a vnějších rušivých signálů systému 4WS. Možné schéma řízení stability vozidla 4WS je znázorněno na obr. 4.

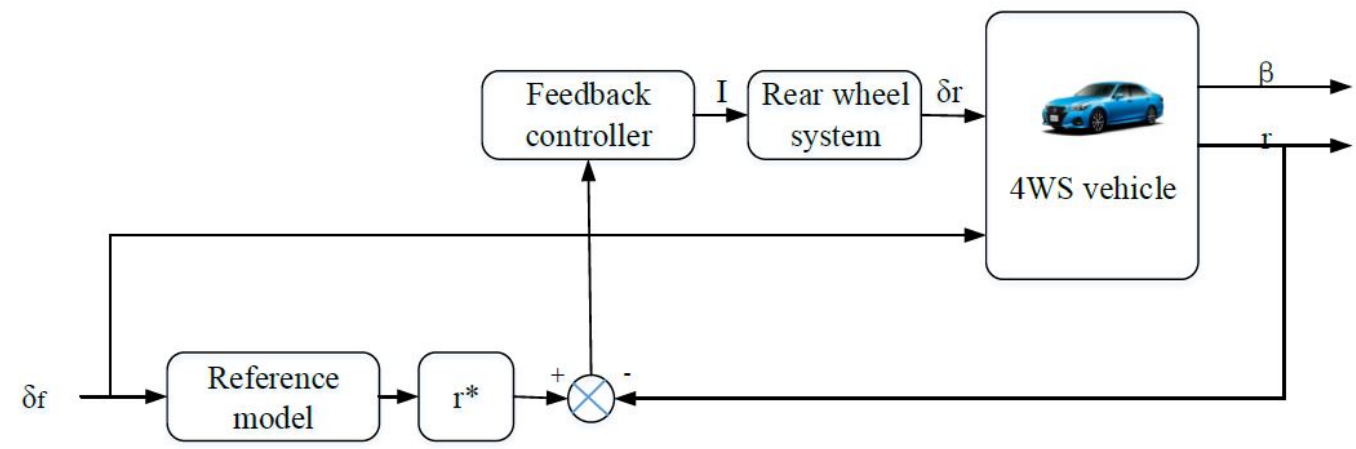

Obr. 4 Schéma řízení stability vozidla 4WS (Zhou, 2019)

Regulátor zpětné vazby je navržen tak, aby minimalizoval chybu rychlosti vybočení vozidla s referenčním modelem. Sledování rychlosti stáčení je nastaveno tak, aby se ideálně řídilo referenčním modelem. Na základě zpětné vazby systém vyhodnotí úhel natočení zadního kola. Díky tomu je dosaženo lepší stability vozidla. Nutno zmínit, že systém obsahuje nejistoty, např́klad rozdíl mezi matematickým modelem a skutečností (Zhou, 2019).

\subsection{Porovnání výhybných manévrů}

Na obr. 5 je viditelná požadovaná teoretická ideální stopa vozidla ve srovnání se stopou vozidel s řízením kol zadní nápravy a bez řízení. Je zřejmé, že vozidlo se správně řízenou zadní nápravou se velice blíží ideálnímu výhybnému manévru (Brabec, 2016).

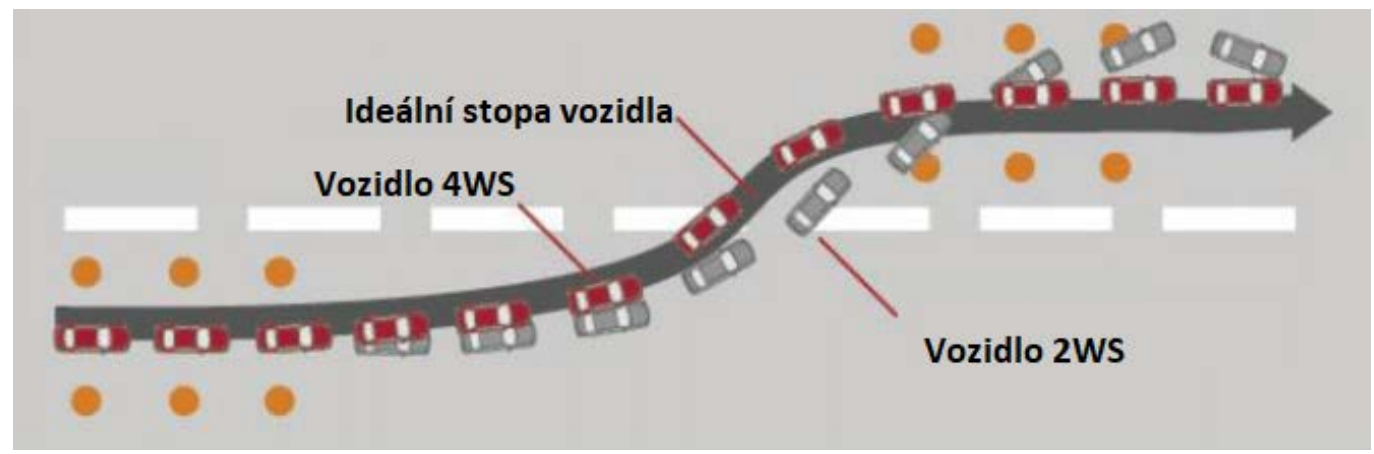

Obr. 5 Porovnání stop vozidel 4WS a 2WS (Brabec, 2016)

\section{POČÁTKY SYSTÉMŮ NATÁČENÍ VŠECH ČTYŘ KOL}

Historie natáčení kol obou náprav vozidel se začala psát již počátkem minulého století. Počátky těchto systému patří do zemědělského průmyslu na území Austrálie (Buch, 2009). Další vývoj proběhl až před druhou světovou válkou ve vojenské technice. 


\subsection{Zemědělské stroje}

První stroj se zmiňovaným natáčením kol obou náprav je z roku 1910 traktor Caldwell. Jednalo se o nesouhlasné natočení náprav právě pro využití menšího poloměru otáčení a tím pádem lepší průjezd na omezeném prostoru při práci na poli. Australský traktor byl velice průlomový, nejen natáčením obou náprav, ale také zdvihacím systémem, který uměl zdvihnout až 8 pluhů z hloubky 10 placů (Lácha, 2018).

Skvělá manévrovatelnost vozidla, kterou zajistil jednoduchý mechanický systém. Vozidlo nahradilo několik vozidel tehdejší doby. Nevýhodou stroje na obr. 4 je přidaný další mechanický prvek, který potřeboval patřičné servisní úkony. Mezi základní úkony patřilo čištění, mazání a vymezení vůlí.

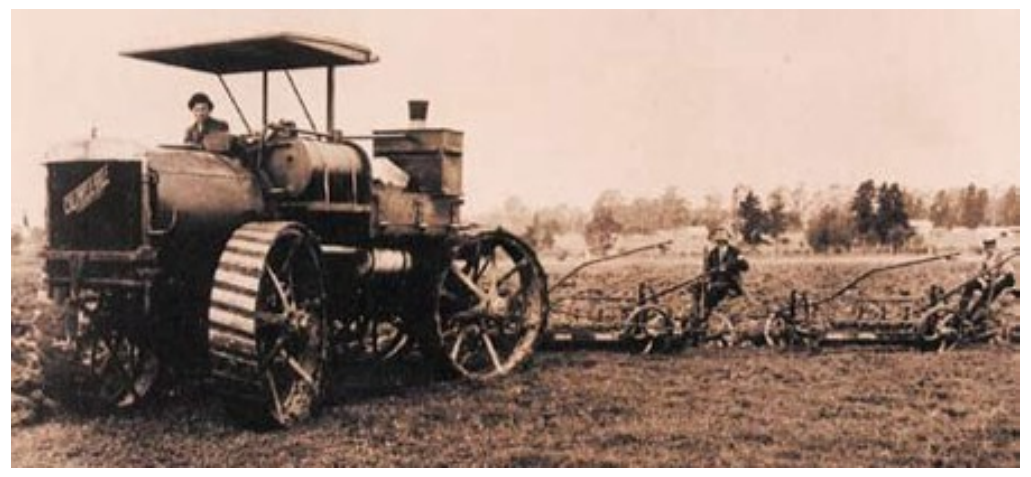

Obr. 6 Caldwell 1910 (Buch, 2019)

\subsection{Vojenské stroje}

Systém, který se osvědčil v zemědělských strojích, se po několika letech dostal i do osobních terénních vozidel. Využívala jej německá armáda ve vozech Mercedes Benz 170 VL na obr. 5. Systém zůstal stále mechanický, byl robustní, takže umožnoval pohyb vozidla i v náročném terénu, zejména v lesním porostu (130VL, 2016).

Obrovskou výhodou ve válečném období byla jistě znatelně lepší průjezdnost vozidla v terénu a skvělá manévrovatelnost na malém prostoru. Nevýhodou systému je přidání dalšího konstrukčního celku, který se může vdůležitých válečných situacích poškodit. Nepř́íznivá je samotná hmotnost systému, která zvýší hmotnost vozidla a jeho spotřebu (Vysoký, 2017).

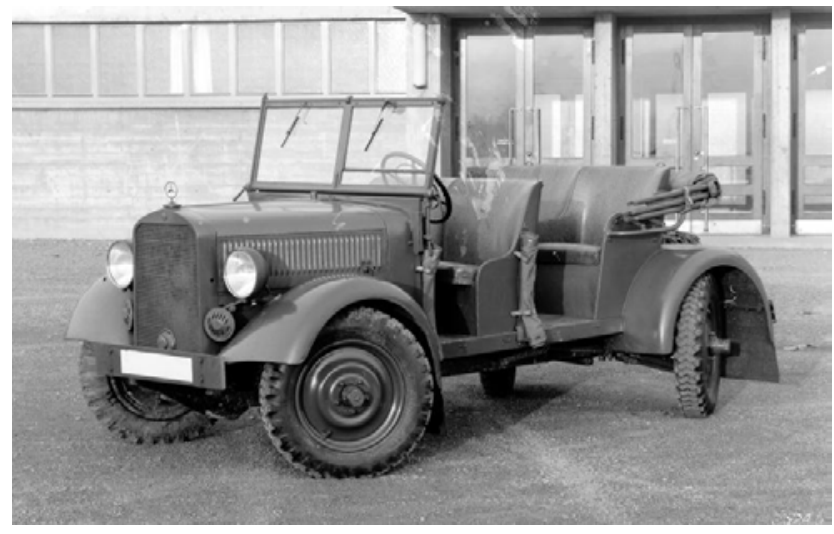

Obr. 7 Mercedes Benz 170 VL (130 VL, 2016) 


\section{SYSTÉMY NATÁČENÍ KOL ZADNÍ NÁPRAVY DEVADESÁTÝCH LET}

Další znatelný vývoj přišel v osmdesátých a devadesátých letech minulého století v japonských automobilkách Honda, Mazda a Nissan. Evropským zástupcem řízení kol zadní nápravy byla automobilka BMW.

\subsection{Systém Nissan HICAS a jeho specifikace}

HICAS (High Capacity Actively Controlled Steering) systém je prvním průkopníkem konce osmdesátých let. Nedostal se k sériové výrobě. Umožňoval však souhlasné i nesouhlasné natočení kol pomocí elektrohydraulického systému. Jeho výhodou je řízení kol zadní nápravy v závislosti na rychlosti vozidla. Nevýhodou je malý úhel natočení kol a vychýlení os kol z důsledku pohybu ramena nápravy. Tento systém nebyl sériově vyráběn. Podle koncepce je zřejmé, že nejvíce namáhanou součástí je uložení natáčecí výkyvné nápravy (Lažanský, 2017).

\subsection{Systém Honda Fouf wheels steering a jeho specifikace}

Systém od automobilky Honda byl prvním sériově umístěným systémem ve voze Prelude III (Dusil, 2017). Fungoval čistě mechanicky. Úhel natočení předních kol se z přední převodky řízení přenášel přes kloubový hřídel do převodky zadní. Systém se začal vyrábět z důvodu potřeby zvýšit směrovou stabilitu vozidla. První Hondy se chovaly jako nedotáčivé, což se natáčením zadních kol změnilo. Honda Prelude se stala tehdejším vítězem v kategorii sportovních vozů ve slalomu. Systém má velmi jednoduché řešení a je vhodný zejména pro nižší rychlosti. Nevýhodou systému je těžký mechanický konstrukční celek, bez možnosti systém řídit v závislosti na jiném faktoru, než je natočení volantu. Neuvažuje rychlost vozidla, ani tuhost pneumatik. Montáž systému s sebou přináší mechanické opotřebení dalších součástí vozidla a více servisních úkonů při běžné údržbě.

\subsection{Systém Mazda a jeho specifikace}

U systému Mazdy je také použit hřídel (tyč) vedoucí od převodky řízení přední nápravy k té zadní, jako u mechanického systému od Hondy. Hřídel od přední převodky řízení natáčel hlavní kuželové soukolí v převodce rrízení zadních kol. To však bylo současně prostřednictvím řídícího třmenu se šnekovým převodem spojeno s krokovým elektromotorem. Jeho natáčením docházelo ke změně polohy řídícího třmenu, který je současně otočně spojený s řídicí tyčí. Ta byla dále spojena s pístem řídicího hydraulického rozvaděče, který měnil tlak kapaliny generované olejovým čerpadlem. Podle toho se tak zadní kola vychylovala více či méně, př́ípadně ve stejném nebo opačném smyslu než přední kola. Jak se čep krokového elektromotoru vysouval či zasouval, měnil se také úhel řídicí tyče. Do rychlosti $40 \mathrm{~km} / \mathrm{h}$ se zadní kola natáčela v opačném smyslu, při této rychlosti se nenatáčela, naopak od uvedené rychlosti výše se natáčela stejně jako přední kola. Výhodou oproti předešlým systémům je základní elektronické řízení natočení kol zadní nápravy závislé na úhlu natočení volantu a rychlosti jízdy, z tohoto důvodu je vhodnější pro vysoké rychlosti. Nevýhodou systému je vyšší pořizovací cena. Přidáním několika dalších členů přibývají i náklady na provoz vozidla. Častější intervaly pravidelné údržby, výměny olejů, řešení netěsností systému (Brabec, 2010). 


\section{SYSTÉMY POUŽÍVANÉ U SOUČASNÝCH VOZIDEL}

S odstupem několika desítek let se četnost využití systému řízení všech kol nijak extrémně nerozšíríila. Používá ji několik vybraných vozů s vyšší pořizovací cenou, kde plní úlohu lepší manévrovatelnosti. Řešení stability silničních vozidel v kritických chvílích v devadesátých letech vystřídal systém ESP.

\subsection{Hromadná přeprava osob}

Systémy řízení zadní nápravy se používají pro lepší manévrovatelnost i u autobusů na obr. 6 . Autobusy pro dálkovou přepravu osob mívají díky své délce z pravidla 3 nápravy. Dvě zadní pak mohou být rozdělné na hnací (dvoumontáž) a řiditelnou. Systémy ř́zené zadní nápravy se využívají i u některých kloubových autobusů používaných v městské dopravě. Potřeba přepravit vyšší počet pasažérů ve vozidlech a snaha snížit počet vozidel v městském provozu s sebou nese nutnost využívat tyto systémy, aby vozidla mohla v provozu bezpečně projíždět (The new Mercedes-Benz CapaCity L, 2015).

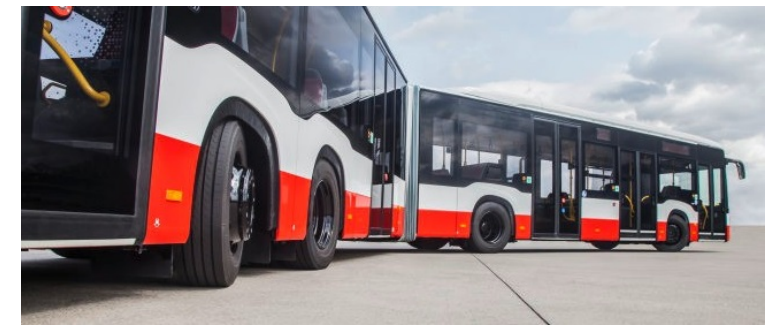

Obr. 8 Mercedes CapaCity L (The new Mercedes-Benz CapaCity L, 2015)

\subsection{Nákladní doprava}

Nákladní doprava využívá systémy natočení zadní nápravy pro lepší manipulaci vozidel na staveništích, ve městech a při převozu nadměrných nákladů. Dnešní dlouhá nákladní vozidla mají z pravidla jednu nebo více hnaných náprav. (viz obr. 7) První a poslední náprava je často řiditelná. Zadní řiditelná náprava se dá pro běžný provoz zdvihnout, sníží se tím valivý odpor a opotřebení pneumatik. Využití více natáčecích náprav je u speciálních strojů, které jsou osazeny např́iklad jeřáby a na návěsech pro přepravu velkých pracovních strojů nebo nadměrného nákladu. Systém u návěsů je například řízen dle zalomení tahače, podle tohoto úhlu řídí hydromechanický systém nesouhlasné natočení kol zadních náprav tak, že poslední náprava je nejvíce natočena. Touto konstrukcí konec návěsu opisuje svoji dráhu a je tak možné projet i úzká místa, kruhové objezdy aj. (Kopecký, 2019).

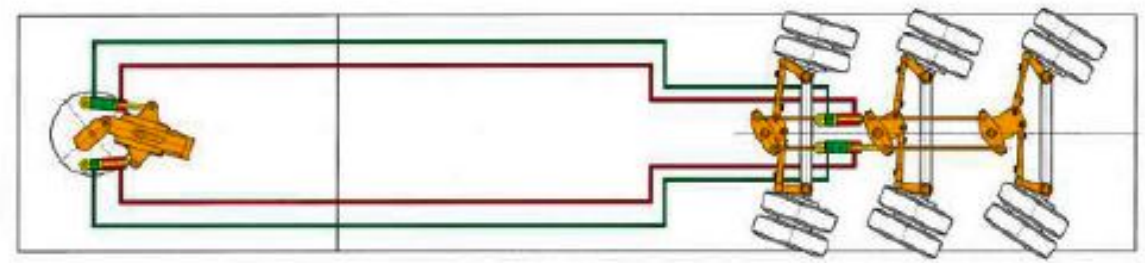

Obr. 9 Systém řízení speciálních návěsů (Dresler, 2009)

\subsection{Renault Active drive}

Tento systém pokračoval ve vývoji z devadesátých let minulého století. O vývoj se postarala firma Renault a Renault Sport Technologies v roce 2007. Sériově byl systém umístěn ve voze Renault Laguna GT a přinesl s sebou několik konstrukčních a systémových inovací (Wagenknecht, 2017). 
Novinkou v systému byla komunikace natáčení zadní nápravy s řídící jednotkou, díky tomu mohl systém zpracovávat veškeré informace o jízdním stavu vozidla. Důležitá komunikace systému byla s jednotkou stabilizačního programu ESP a ASR. (rychlost vozidla, úhel natočení volantu, brzdný účinek aj.) V závislosti na rychlosti jízdy se kola natáčely nesouhlasně do $60 \mathrm{~km} / \mathrm{h}$ a od této rychlosti se natáčely souhlasně. Běžný úhel natočení kol je do $2^{\circ}$ (Wagenknecht, 2017). Maximální úhel natočení v kritické situaci je 3,5 (Wagenknecht, 2017). Výhodou tohoto systému je, že se kola zadní nápravy natočí při kritickém brzdění na rozdílné adhezi jednotlivých kol samostatně. A částečně tak stabilizují směr jízdy. Systém provádí korekci každých 10 milisekund (Wagenknecht, 2017), (Pilisiewicz, Kaczynski, 2017).

\subsection{Systém Volkswagen}

Elektronicky ovládaný systém zadní nápravy funguje ve dvou režimech. V prvním režimu při rychlosti jízdy do $37 \mathrm{~km} / \mathrm{h}$ natočí zadní kola proti směru natočení kol přední nápravy, maximálně však o $5^{\circ}$. V případě rychlejší jízdy se kola obou náprav natáčí souhlasně (Nový Volkswagen Touareg: Systémy pohonu a podvozku, 2018).

Poloměr zatáčení v nízkých rychlostech se změnil na 11,19 metru místo původních 12,19 metru, tím pádem vozidlo získá lepší manévrovatelnost v úzkých uličkách. Komunikuje také se systémem pro manévrování s přívěsem, tím pádem pro soupravu zajišt'uje snadnější ovládání při couvání. Nevýhodu systému je vyšší pořizovací cena a přidání dalšího konstrukčního celku do vozidla, který je třeba dle servisních intervalů udržovat. Systém je aplikován jen s nejvyšší výbavou. Servisní intervaly systému řízení zadní nápravy ve vozidlech s takovouto pořizovací cenou nejsou tolik finančně náročné, $v$ poměru cen za servisní intervaly na vozidle jako celku (Nový Volkswagen Touareg: Systémy pohonu a podvozku, 2018).

\subsection{Systémy BMW a AUDI}

BMW svůj první systém představilo na počátku devadesátých let v legendárním voze 850CSi. V současné době ho využívá zejména ve vozech řady 7 . Audi se svým vývojem nezůstala pozadu. Natáčení zadní nápravy v současnosti využívá ve vyšších výbavách A6 nebo Q7. V současné době nese systém AUDI název All wheel steering a systém BMW se nazývá Integral active steering. Oba tyto systémy fungují na elektromechanickém principu a jsou si velice podobní.

\subsubsection{Popis systémů}

Systém AUDI i BMW aktivně spolupracují se všemi doplňkovými komfortními systémy, takže je pro řidiče velmi pohodlné parkovat, projíždět úzkými uličkami nebo např́iklad nechat systém automaticky hladce couvat s přívěsem. Systém je instalován jen do vozidel vyšších tříd a má vysokou pořizovací cenu. Instalován je z pravidla do vyšších výbav vozidla. V provozu jsou tyto systémy řádově desítky měsíců, proto se u nich neprojevují závažnější závady. Výhodou těchto elektromechanických systémů je, že není třeba využití hydraulického systému ve vozidle, technicky vzato jsou pak téměř bezúdržbové a šetrnější k životnímu prostředí. Základním vzniklým servisním intervalem bude výměna mazací náplně. Provoz v několika dalších desítkách měsíců může ukázat chybové konstrukční součásti (Heissing B., Ersoy M., 2008).

\subsubsection{Specifikace All wheel steering}

Systém dokonale navazuje na dynamické řízení přední nápravy, kde se úhel natočení kol vůči natočení volantu mění v závislosti na rychlosti. Při nízké rychlosti se díky možnosti natočení zadních kol až o $5^{\circ}$ proti směru řízení se u vozidel Audi A8 a A8L zmenší poloměr otáčení přibližně o 1 m. Nový poloměr otáčení u Audi A8 je tedy 11,4 m. Při střední a vysoké rychlosti se kola natáčí shodně s předními a natočí se maximálně o $2^{\circ}$. Systém zasahuje do řízení i na mezích dynamiky jízdy, kdy se na každé straně automobilu pod jízdními koly vyskytuje jiný součinitel tření (Audi A8 - Dynamic all-wheel steering, 2017). 


\subsubsection{Specifikace Integral active steering}

Systém u BMW obdobně jako u Audi spolupracuje s elektricky řízeným sloupkem volantu, který zajišt'uje dynamické řízení přední nápravy. K natočení zadních kol dochází však maximálně o $3^{\circ}$. Nesouhlasně se kola natáčejí až do rychlosti $60 \mathrm{~km} / \mathrm{h}$. Od této rychlosti je pak kola natáčejí souhlasně. Systém spolupracuje se stabilizací podvozku, a poroto může pomoci řešit kritické situace. Řidič však vždy zůstává zapojen do řízení (Integral Active Steering, 2017).

\section{ZHODNOCENÍ SYSTÉMŮ POUŽÍVANÝCH V SOUČASNÉ DOBĚ}

Všechny tyto systémy mají v současnosti své obdivovatele a uživatele. Nicméně ve většině případů se jedná o drahý rrídící prvek, který nemusí vyhovovat každému zákazníkovi. Proto se systémy prozatím u osobních vozidel nižších tříd nevyužívají. U zmiňovaných velkých osobních vozidel se jedná o systém, který skvěle napomáhá manévrovatelnosti v městském provozu a při parkování. Při rychlé jízdě, kterou můžeme připodobnit jízdě po dálnici, systém přidá na komfortu jízdy, který nejvíce pocítí pasažéři sedící na zadních sedadlech. Využití u vozidel nákladní přepravy a hromadné dopravy osob je mnohdy nevyhnutelné.

\section{ZÁVĚR}

Systémy v současných vozidlech jsou velice propracované a zvládají částečně zastoupit řidiče v řízení vozidla. Veškeré poznatky z řízení kol obou náprav budou jistě značně využity a rozšířeny u vozidel s autonomním řízením. Za zmínku jistě stojí, že současné systémy natáčí zadními koly jen o pár jednotek stupňů, a to oběma koly nápravy společně.

U nových systémů v plánovaných autonomních vozidlech se získá možnost zvyšovat bezpečnost posádky díky řízení zadní nápravy. Již bylo zmíněno, že vozidlo s řízenou zadní nápravou je stabilnější a ovladatelnější. $V$ tu chvíli, kdy budou snímače na vozidle a počítač (software) bude vyhodnocovat pohyb vozidla, vznikne možnost díky tomuto systému řízení minimalizovat střety osobních vozidel. Nebo jim možná úplně zabránit

Dle našeho názoru vede cesta ve využití systému, který bude natáčet jednotlivými koly zadní nápravy zvlášt', tedy každé kolo bude mít svůj elektromechanický systém. Tedy mezi koly automobilu nebude žádná mechanická vazba. Tím pádem bude systém schopen lépe regulovat natočení kol podle správného pólu pohybu. Natočení obou kol bude v závislosti na několika faktorech, hlavně na rychlosti vozidla, povrchu vozovky a natočení kol přední nápravy.

\section{Poděkování}

Příspěvek vznikl na základě podpory projektu SGS_2020_009 "Vybrané výzkumné problémy z oblasti dopravních prostředků a infrastruktury".

\section{Literatura}

Audi A8 - Dynamic all-wheel steering. 2020. Audi Technology portal, [Online]. Dostupné z: https://www.audi-technology-portal.de/en/chassis/wheel-suspension-steering/audi-a8-dynam ic-all-wheel-steering [př́stup: 19.01.2020].

Brabec, P., 2010. Systémy řízení zadních kol automobilu. Verze 2010. Liberec TUL. Dostupné z: https://www.google.com/url?sa=t\&rct=j\&q=\&esrc=s\&source=web\&cd=\&ved=2ahUKEwiZxorG 7YXqAhWFqqQKHXv9C9cQFjAAegQIBBAB\&url=http\%3A\%2F\%2Fintech2.tul.cz\%2Fdokumenty \%2Fvystupy_z_projektu\%2F01 TUL\%2F002_In-TECH\%25202_Brabec_Syst\%25C3\%25A9my\% 2520\%25C5\%2599\%25C3\%25ADzen\%25C3\%25AD\%2520zadn\%25C3\%25ADch\%2520kol\%2 520automobilu_2010.pdf\&usg=AOvVaw0pjGtmlzMrarTTNpOz5-qv [cit. 10.5.2020]. 
Brabec, P., Vozenilek, R., Lachman, M. 2016. Stability Simulation of a Vehicle with Wheel Active Steering, In: MATEC Web of Conferences 40, 02025.

<https://doi.org/10.1051/matecconf/20164002025>

Caldwell, V. 2001. Wikipedia: the free encyclopedia. [Online]. San Francisco (CA): Wikimedia Foundation, 2001. Dostupné z: https://de.wikipedia.org/wiki/Caldwell-Valec [cit. 18.04.2020].

Dresler, P. 2009. Řízení silničních vozidel. Bakalářská práce. Ostrava, Vysoká škola Báňská.

Dusil, T. 2017. Aktivní řízení 4WS slaví 30 let: Všemi čtyřmi brzdit, všemi čtyřmi řídit!. Auto.cz. [Online]. Dostupné z: https://www.auto.cz/aktivni-rizeni-4ws-slavi-30-let-vsemi-ctyrmi-brzditvsemi-ctyrmi-ridit-108507 [cit. 21.04.2020].

Heissing, B. a Ersoy, M. 2008. Chassis Handbook: Fundamentals, Driving Dynamics, Components. 2. Weisenbaden, 2008, GWV Fachverlage.

Integral Active Steering. 2017. BMW Insights and Features, [Online], Dostupné z: https://www.ppsl-bmw.sg/insights/Integral-Active-Steering [cit. 18.01.2020].

Kopecký, V. 2019. Steer by wire pro řízení kol na více nápravách. Diplomová práce. Pardubice, Univerzita Pardubice.

Lácha, V. 2018. Návrh stavebnicového řešení dvou řiditelných náprav u vozidla. Bakalářská práce. Plzeň, Západočeská univerzita v Plzni.

Lažanský, M. 2017. Řízení zadních kol: Žádný výstřelek poslední doby, řada aut ho měla dávno. Autorevue.cz. [Online]. Dostupné z: https://www.autorevue.cz/rizeni-zadnich-kol-zadnyvystrelek-posledni-doby-rada-aut-ho-mela-davno [cit. 11.05.2020].

Mercedes Benz. [Online]. Dostupné z: https://mercedes-benz-publicarchive.com/ marsClassic/en/instance/ko/170-VL.xhtml?oid=4279 [cit. 20.03.2020].

Návěsy řady STZ počet náprav 2-10. 2019. Goldhofer. Dostupné z: http://www.goldhofer.cz/ navesy-rady-stz.php [cit. 11.01.2020].

Pilisiewicz, J., Roman K.. 2017. Geometric analysis of maneuverability performance for vehicles with two steering axles. Transport Problems, 12(2), 43-52.

Pokorný, J., Jilek, P. 2014. Splnění Ackermannové podmínky pro systém 4WS. Elektrotechnická zař́zení v dopravě 2014. Pardubice, Univerzita Pardubice, s. 1-6.

„Řízení všech kol“ zmenšuje průměr otáčení. Technické inovace pro nový Touareg - 2. díl. 2017. [Online]. Dostupné z: https://www.volkswagen.cz/svet-volkswagen/novinky/5880technicke-inovace-pro-novy-touareg-2-dil-rizeni-vsech-kol-zmensuje-prumer-otaceni [cit. 11.05.2020].

The new Mercedes-Benz CapaCity L: show vehicle in detail. 2019. Daimler. [Online]. Dostupné z: https://media.daimler.com/marsMediaSite/en/instance/ko.xhtml?oid=9904821

[cit. 21.02.2020].

Vysoký, J. 2017. Návrh řešení dvou řiditelných náprav u osobního vozidla. Bakalářská práce. Plzeň, Západočeská univerzita v Plzni.

Wagenknecht, M. 2017. Technologie $\mathrm{v}$ autech: natáčení zadní nápravy. fDrive.cz. [Online]. Dostupné z: https://fdrive.cz/clanky/technologie-v-autech-nataceni-zadni-napravy-706. [cit. 19.04.2020].

Xu, X. F., Liu, X. H., Chen, W., Zhou, C., a Cao, B. W. 2020. Improving Handling Stability Performance of Four-Wheel Steering Vehicle Based on the H2/H infinity Robust Control, Applied Sciences, 9, 857. <https://doi.org/10.3390/app9050857> 